Table 3

Tests to be performed in the partner of a carrier to determine the risk of having a child with severe disease

\begin{tabular}{|c|c|}
\hline $\begin{array}{l}\text { Disorder found in } \\
\text { one partner }\end{array}$ & $\begin{array}{l}\text { Test to be carried out in } \\
\text { other partner to exclude } \\
\text { severe disease risk in a child }\end{array}$ \\
\hline$\beta$-thalassaemia carrier & $\begin{array}{l}\mathrm{FBE}, \mathrm{Hb} \text { electrophoresis, to exclude } \\
\beta \text {-thalassaemia and } \delta \beta \text {-thalassaemia } \\
\text { carrier state, and } \mathrm{Hb} S, \mathrm{E}, \mathrm{O}, \mathrm{D}, \mathrm{C} \\
\text { and Lepore }\end{array}$ \\
\hline $\begin{array}{l}\text { Carrier of } \mathrm{Hb} \text { Lepore, } \\
\delta \beta \text {-thalassaemia, } \mathrm{Hb} \mathrm{S}, \mathrm{C} \text {, } \\
\mathrm{D}, \mathrm{E} \text { or } \mathrm{O}\end{array}$ & as for $\beta$-thalassaemia carrier \\
\hline $\begin{array}{l}\text { Two gene deletion } \\
\alpha \text {-thalassaemia }(--/ \alpha \alpha)\end{array}$ & $\begin{array}{l}\mathrm{FBE}, \mathrm{Hb} \text { electrophoresis, } \\
\mathrm{HbH} \text { inclusion prep, DNA analysis (to } \\
\text { exclude risk of having a child with } \\
\mathrm{HbH} \text { disease or Bart's hydrops } \\
\text { syndrome) }\end{array}$ \\
\hline $\begin{array}{l}\text { Single gene deletion } \\
\alpha \text {-thalassaemia } \\
\text { (- } \alpha / \alpha \alpha \text { or }-\alpha /-\alpha)\end{array}$ & $\begin{array}{l}\text { as for two gene deletion } \\
\alpha \text {-thalassaemia to identify risk of } \\
\text { having a child with } \mathrm{HbH} \text { disease }\end{array}$ \\
\hline
\end{tabular}

of iron status. If possible the father should be tested. If a noniron deficient partner has evidence of a thalassaemia carrier state or other haemoglobinopathy, then the woman should have full testing, including DNA analysis to adequately define the risk of them having a child with severe disease (Table 3 ).

\section{Summary}

The identification of carriers of thalassaemia and other clinically significant haemoglobinopathies is a two-stage process. Initially evidence for the carrier state is sought by carrying out a full blood examination and $\mathrm{Hb}$ electrophoresis. Iron deficiency can be excluded as a complicating factor by iron studies in individuals who show a haematological abnormality consistent with this diagnosis. In this relatively simple way evidence for all but single gene deletion $\alpha$-thalassaemia (and most non-deletional point mutations) will usually be obtained. Further studies including DNA analysis can then be carried out for final clarification of the carrier state. In this way it is usually possible to identify all but a few mutations and to provide informative counselling for individuals and couples.

E-mail: don.bowden@med.monash.edu.au

\section{REFERENCES}

1. Higgs DR. alpha-Thalassaemia. Ballieres Best Pract Res Clin Haematol 1993;6:117-50.

2. The laboratory diagnosis of haemoglobinopathies. $\mathrm{Br} \mathrm{J}$ Haematol 1998;101:783-92.

3. Hendy JG, Monagle PT, Bowden DK. Antenatal screening and prenatal diagnosis of thalassaemia. Med J Aust 1999;170:623-4.

4. Wasi P, Disthasongchan P, Na-Nakorn S. The effect of iron deficiency on the levels of haemoglobins A2 and E. J Lab Clin Med 1968;71:85-91.

5. Williams TN, Maitland K, Ganczakowski M, Peto TE, Clegg JB, Weatherall DJ, et al. Red blood cell phenotypes in the alpha + thalassaemias from early childhood to maturity. Br J Haematol 1996;95:266-72.

\section{Self-test questions}

The following statements are either true or false (answers on page 131)

7. Thalassaemia and iron deficiency can cause microcytosis of red blood cells.

8. Babies who carry mutations for both $\alpha$-thalassaemia and $\beta$-thalassaemia usually die at birth.

\title{
Gardener's corner
}

Australians are increasingly using complementary medicines. Australian Prescriber will therefore be commenting occasionally on some of these medicines. This is not an endorsement of their effectiveness, but an attempt to provide health professionals with some information about the products their patients may be taking.

\section{Agnus castus fruit}

The fruits of the chaste tree (Vitex agnus castus) have historically been used as a remedy for gynaecological problems. While the active ingredient is uncertain, the fruits contain flavonoids and iridoids. Although the mechanism of action is unknown the active ingredient is thought to modulate the secretion of prolactin. It may also bind to opioid receptors.

A recent placebo-controlled trial studied an extract (Ze440) of agnus castus fruit in 170 women with premenstrual syndrome. ${ }^{1}$ After three months, women who took the extract reported a greater reduction in symptoms than the women taking a placebo did. There were significant reductions in anger, irritability, headache, and breast fullness.
The fruit is not known to have serious adverse effects and none emerged in this trial. It is not known if there are any significant drug interactions with the extract.

Although significantly more women responded to the extract only $52 \%$ had an improvement of more than $50 \%$ in their symptoms. (24\% of the women taking a placebo had a greater than 50\% improvement.) The trial did not investigate if these benefits were maintained after the end of the study. Other formulations cannot be assumed to have the same efficacy as the extract used in this trial.

\section{REFERENCE}

1. Schellenberg R. Treatment for the premenstrual syndrome with agnus castus fruit extract: prospective, randomised, placebo controlled study. Br Med J 2001;322:134-7. 